\title{
RESEARCH AND TOURISM AFFECT POSITIVELY \\ THE OCCUPANCY PATTERN OF LOXODONTA CYCLOTIS (ELEPHANTIDAE) IN TAÏ NATIONAL PARK, CÔTE D'IVOIRE
}

\author{
Malé R. Kely ${ }^{1,2} \mathbb{D}$, Célestin Y. Kouakou ${ }^{1,2} \mathbb{D}$, Jean-Claude K. Béné ${ }^{1}$, Manouhin R. Tiedoué ${ }^{3}$, \\ Abdoulaye Diarrasouba ${ }^{3}$, Adama Tondossama ${ }^{3}$, Hjalmar S. Kuehl ${ }^{4}{ }^{\mathbb{D}}$, Matthias Waltert ${ }^{5}$ iD \\ ${ }^{1}$ Jean Lorougnon Guédé University, Côte d'Ivoire \\ e-mail:malekely@gmail.com,celestykoua18@gmail.com,benejc@gmail.com \\ ${ }^{2}$ Swiss Centre for Scientific Research in Côte d'Ivoire, Côte d'Ivoire \\ ${ }^{3}$ Ivorian Office of Parks and Reserves, Côte d'Ivoire \\ e-mail: tiedouer@gmail.com,abdoulaye.diarrassouba@oipr.ci,adama.tondossama@oipr.ci \\ ${ }^{4}$ Max Planck Institute for Evolutionary Anthropology, Germany \\ e-mail:kuehl@eva.mpg.de \\ ${ }^{5}$ Georg-August-Universität Göttingen, Germany \\ e-mail:mwalter@uni-goettingen.de
}

Received: 27.01.2020. Revised: 12.12.2020. Accepted: 13.12.2020.

\begin{abstract}
The decline and isolation of wild megafauna populations are increasingly recognised in Africa. In Côte d'Ivoire where elephants are a national symbol, the Taï National Park (TNP) is a key remaining habitat for Loxodonta cyclotis. However, the interactions between L. cyclotis and its current environmental conditions are less known. This study aims at determining the factors that affect the occupancy patterns of the species at TNP for guiding conservation decision-making. We assessed the species occupancy probability and factors that affect its distribution based on habitat variables and observations from 87 camera traps installed for 120 days within TNP. We used an occupancy model to determine the variables that significantly affect $L$. cyclotis distribution and to estimate their occupancy probability by site of camera traps installation. We also produced a predictive species distribution map by interpolating occupancy probability values at trapping sites. The key factors that drive the L. cyclotis distribution in the TNP were the distance to the nearest research or ecotourism areas, the distance to the periphery and the rate of poaching index of the installation site. Occupancy probability decreased with closer distance to the TNP periphery and increasing poaching pressures, while it increased with the proximity of research or ecotourism areas. The predictive distribution map indicated that the northwestern and southwestern areas of the TNP had a higher probability $(p>0.6)$ of L. cyclotis occurrence, compared to other parts of the Protected Area. These results confirm the positive effect of scientific research and ecotourism activities that favour L. cyclotis (and thus other wildlife) conservation. So those activities have to be promoted along with antipoaching strategies.
\end{abstract}

Key words: camera trap, distribution factor, elephant conservation, occupancy model, Protected Area

\section{Introduction}

At a global scale, the large megafauna is collapsing at an unprecedentedly accelerated rate and locating accurately areas occupied by remaining populations is of utmost importance for ecological research and for conservation decision-making (Craigie et al., 2010; Ripple et al., 2014). In Africa, large mammals are increasingly threatened and isolated throughout their range even within Protected Areas where their populations have decreased by $59 \%$ between 1970 and 2005 (Craigie et al., 2010).

Among the megafauna, elephants (Loxodonta sp.) represent the largest mammals in Africa having numbered millions of individuals before colonial periods (Douglas-Hamilton, 1987). However, the populations of Loxodonta cyclotis Matschie, 1900 and Loxodonta africana Blumenbach, 1797 have been decimated with an estimated yearly death rate of 30000 individuals in recent decades (Wittemyer et al., 2014; Chase et al., 2016). Recent estimates of the L. africana population from surveys across its vast range of 2300000 $2400000 \mathrm{~km}^{2}$ indicated about 415000 surviving individuals (Chase et al., 2016).

The population status and threats to elephants are believed to vary among species and with sub-regional or local conditions (Thouless et al., 2016). For instance, with less than $3 \%$ of the population of both species, West Africa holds the smallest regional population on $5 \%$ of the total elephant range (Maisels et al., 2013; Chase et al., 2016). Unfortunately, the disappearance of elephants from West Africa is expected soon as the region has already lost $90 \%$ of its original elephant range during the XX century (Bouché 
et al., 2011). Although climate change may also affect elephant populations (Hetem et al., 2014), the causes of their decline are mainly linked to human activities which include hunting for the ivory market, the degradation and loss of natural habitat due to overexploitation of resources, and unsustainable agricultural practices (Maisels et al., 2013; Thouless et al., 2016).

Côte d'Ivoire, a country in West Africa that has the elephant as its national emblem, is no exception (Thouless et al., 2016). In Côte d'Ivoire, the Loxodonta cyclotis population has fallen from 1611 in 1994 to 225 today, representing a population decline of $86 \%$ during the latest decades (Kouakou et al., 2020). At the same time, the L. cyclotis habitat in the Côte d'Ivoire has been reduced dramatically (Kouakou et al., 2020). The inevitable consequence of this loss of forest cover is the shrinking of the species' range which is currently mainly restricted to Protected Areas (Thouless et al., 2016; Kouakou et al., 2020). These remaining habitats are in general not isolated. However, they are also subject to various anthropogenic threats such as poaching, agricultural encroachment and gold panning (Barima et al., 2016; Thouless et al., 2016). The colonisation of Protected Areas increased during the crisis decade of 2002-2011 (Ousmane et al., 2020). Fortunately, The Taï National Park (TNP) seems to be one of the few national parks in Côte d'Ivoire that has not suffered significant damage during this decade of crisis (Kouakou et al., 2020). The TNP is a biodiversity hotspot and the largest forested habitat under protection in West Africa (Kolongo et al., 2006). This area is one of the last refuges for L. cyclotis in the sub-region even though its population size is likely to be less than 200 individuals (Thouless et al., 2016; Tiedoué et al., 2018).

Although L. cyclotis in the TNP have been the subject of some studies (Kely et al., 2019), there is still a lack of understanding of local environmental and anthropogenic conditions driving their distribution and its population survival in the TNP. Such information is, however, required for identifying threats, preventing human-wildlife conflicts, prioritising conservation and management strategies (Snyder et al., 2019).

The overall objective of this study is to contribute to a better understanding of the L. cyclotis distribution in the TNP in order to improve the conservation of its population. More specifically, this research aims at determining the key factors that drive the L. cyclotis distribution in the TNP by establishing a predictive distribution map of $L$. $c y$ clotis based on the species' occupancy probability.

This study is based on the hypothesis that the Loxodonta cyclotis distribution in the TNP is influenced by anthropogenic and natural factors. More specifically, the presence of researchers and ecotourists inside a given Protected Area is believed to provide a protective effect for $L$. cyclotis (or wildlife populations). Poaching activities, distance to the periphery of a Protected Area and altitude are assumed to have a negative influence on the L. cyclotis distribution. Previous studies have shown such a contribution of these variables on the TNP wildlife (Köndgen et al., 2008; Campbell et al., 2011; Bogui et al., 2016; Diarrassouba et al., 2019).

\section{Material and Methods}

\section{Study site}

The TNP covers an area of $5360.16 \mathrm{~km}^{2}$ including the N'Zo Partial Faunal Reserve. It is located in the southwest of Côte d'Ivoire between $6.783333{ }^{\circ} \mathrm{W}$ and $7.416667{ }^{\circ} \mathrm{W}$, and between $5.133333^{\circ} \mathrm{N}$ and $6.400000^{\circ} \mathrm{N}$ (Fig. 1).

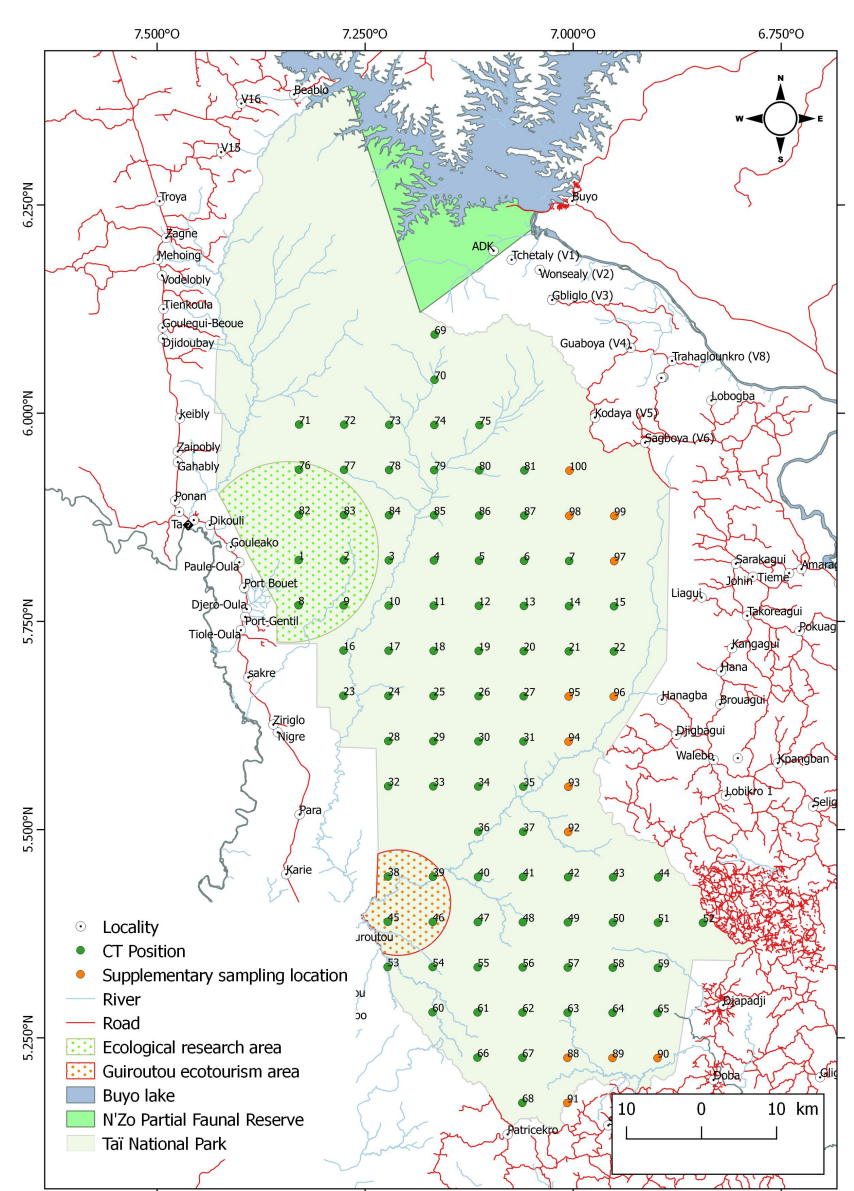

Fig. 1. Study site and sampling design in the Taï National Park (Côte d'Ivoire). 
The relief of the TNP generally consists of a set of fairly uniform hills except for the southern region of this Protected Area which has a more rugged terrain, including Mount Niénokoué (396 $\mathrm{m}$ a.s.1.) and the Grabo mountain (424 $\mathrm{m}$ a.s.1.) (OIPR, 2014; Konaté \& Kampmann, 2010). The TNP's water system is very dense with many rivers and two major watersheds, namely the River Cavally Basin and the River Sassandra Basin (Scouppe, 2011). The flora of TNP has a high rate of endemism as it is a part of the Sudano-Guinean endemism hotspot area (Yao \& N'Guessan, 2005; Scouppe, 2011). The TNP mainly consists of evergreen rainforest. The northern part of the TNP is mainly covered by Eremospatha macrocarpa and Diospyros mannittiera trees, while the southwest includes water-demanding species such as Diospyros spp. and Mapania spp. (Kolongo et al., 2006). The TNP supports at least 1366 plant species, while $25 \%$ of them are endemics (Scouppe, 2011). The wildlife richness of the TNP is unique, probably because it is isolated by two major rivers (Cavally and Sassandra), flowing on either side of the Protected Area in a north-south direction (Chatelain et al., 2001). The TNP contains approximately 145 mammal species, among which are Loxodonta cyclotis, Cephalophus jentinki Thomas, 1892, Cephalophus zebra Gray, 1838, Cercopithecus diana Linnaeus, 1758 and Choeropsis liberiensis (Morton, 1849) (Chatelain et al., 2001). The main economic activity around the TNP is agriculture (Komena, 2014). The increase of farm areas around the TNP leads to the intensification of the human-wildlife conflict. Hunting and artisanal mining remain major sources of pressure on the TNP (Caspary et al., 2001; N'Goran et al., 2012; OIPR, 2014). According to Caspary et al. (2001), the annual weight of the carcasses of animals killed by occasional hunters around the TNP ranges from $1500 \mathrm{t}$ to $3000 \mathrm{t}$.

\section{Data collection}

We collected data from June 2016 until December 2017 using 87 Bushnell camera traps (CT) with passive sensors. Camera trapping data collection conforms to the methods described by Kely et al. (2019). They were installed following a systematic sampling design consisting of superimposing a grid of $6 \times 6 \mathrm{~km}$ size on the entire TNP. The first grid was chosen in a random way using QGIS 2.10 (www.qgis.org). The centre of each grid cell was used as the installation point for a CT. Given the limited number of CTs available for this study, we sampled only grid cells overlapping with the known Loxodonta cyclotis distribution based on the different biomonitoring reports and surveillance patrol reports. Trapping was carried out for 120 days divided into two phases of data collection, namely phase 1 (from 09.06.2016 to 08.08.2017) and phase 2 (from 10.10.2017 to 09.12.2017). We navigated in the forest to access the CT installation points by using GPS (Garmin 64S model) and a compass (Recta DT220 model). Once at the position indicated for the installation of the CT, a survey within a $200-\mathrm{m}$ radius was carried out to select the most appropriate position, with a view to optimise the L. cyclotis detection by the CT. CTs were attached to robust shrubs at $1.5 \mathrm{~m}$ above ground and $10 \mathrm{~m}$ from potential animal detection points (O'Connell et al., 2011; Burton et al., 2015; Ngama et al., 2018). The potential animal detection points were selected in order to avoid CT sunlight exposure and any obstructions.

The CTs have been set in hybrid mode allowing alternately the recording of video and photographs sequences. The photograph resolution has been minimised (5 mega-pixels) to allow the 32-GB memory cards to record maximum data. The duration of video sequences was set at $60 \mathrm{~s}$, with $1 \mathrm{~s}$ as an interval between two successive detection events.

To determine the factors that influence the occupancy probability of L. cyclotis (response variable) in the TNP, we first hypothesised that the presence of researchers and ecotourists inside a given Protected Area provide a protective effect for L. cyclotis. Secondly, we assumed that poaching activities, distance to the periphery of a Protected Area and altitude have a negative influence on the L. cyclotis distribution. Consequently, five explanatory variables were selected, namely distance to the TNP periphery as a proxy (hereafter - indicator) of human settlements, distance to the nearest research or ecotourism areas as an indicator of researchers and ecotourists' presence, distance to the nearest water body, altitude, and poaching index rate as an indicator of poaching pressure. The choice of these variables was based on previous research results used to explain the distribution of wildlife in general and elephants in particular (Boafo \& Nandjui, 2011; Campbell et al., 2011; N'Goran et al., 2012; Danquah, 2016; Ashiagbor \& Danquah, 2017; Diarrassouba et al., 2019). 
The distance from the point of installation of each CT to the periphery, water body and nearest research or ecotourism areas was determined with GIS (Geographic Information System) tools. The altitude of the installation point was measured with a GPS. For each installation site, a poaching index was obtained based on data collected by OIPR (Ivoirian Office of Parks and Reserves) during phase 12 (2016-2017) of the biomonitoring. That phase corresponds to the $12^{\text {th }}$ year of a biomonitoring data recording at the TNP from 2005. It was chosen because it covered the period of installation of the CTs in the TNP where biomonitoring data were collected along the line transects. The sampling design included 294 transects of 2 $\mathrm{km}$, organised systematically over the entire extent of the TNP (Tiedoué et al., 2018).

\section{Data analysis}

After the CTs were removed, the information on the memory cards was transferred to a computer for sorting. CTs detected at least one $L$. cyclotis individual were designated as positive, while those that did not detect L. cyclotis individuals were designated as negative.

To determine the poaching index, the number of poaching signs (i.e. poachers' camps, poachers' tracks and gun cartridges) counted on each transect was divided by the distance travelled on the transect. Thus, a transect poaching index was assigned to the closest CT site.

Then, multicollinearity between variables was analysed from the calculation of the Variance Inflation Factor (VIF). Thus, a variable is only retained in the model when its VIF is below the threshold value of 2.5 (Allison, 1999).

To determine the occupancy probability of L. cyclotis in the TNP and the best predictors of their presence, we used the occupancy model (MacKenzie et al., 2002, 2006). This model is one of the most commonly used to estimate the occupancy probability and provides an index of abundance (Burton et al., 2015). This model solves the problem of imperfect detection associated with the use of CT (MacKenzie et al., 2006; Ancrenaz et al., 2012). Indeed, by integrating habitat variables and observed detections, it is possible to estimate the occupancy of targeted species in relation to the characteristics of each CT installation site (Ancrenaz et al., 2012). The 120 days of collection were considered as a single season divided into eight sampling occasions, corresponding to 15 days each. Thus, a single-species, single-season model was run, using L. cyclotis' presence-absence data. Modelling was done using the PRESENCE software version 2.12.29 (Hines, 2006). To allow better adjustment of the models, we have added 13 virtual supplementary sampling locations. Thus, in total, 100 sampling locations were distributed in the entire TNP.

We first generated a null model which supposes that the L. cyclotis distribution is homogeneous in the TNP. Then, we generated successive models respectively involving one or more explanatory variables. Finally, we have chosen the models that best explain the L. cyclotis distribution in the TNP as the best models. The choice of best models was made based on the Akaike Information Criterion (AIC) scores. Models with the lowest AIC values with «Delta AICs» less than two were considered the best models. Variables producing the best models were considered the best predictors of the L. cyclotis distribution. We referred to the signs of the beta coefficients of the variables for each selected model to define the direction of the relationship between each explanatory variable and the response variable (occupancy probability). We also computed the naïve occupancy as the number of camera trap sites occupied on sites sampled multiplied by 100 which represents the percentage of the total area occupied (PAO) by a target species (Ancrenaz et al., 2012; Rovero et al., 2014).

An elephant predictive distribution map was built using QGIS 2.18 (www.qgis.org). Loxodonta cyclotis occupancy estimates per installation site were obtained through averaging the best models. The L. cyclotis predictive distribution map was built using the position co-ordinates for each CT, which were linked to the occupancy value obtained from the modelling (Rovero et al., 2014). We used the inverse distance weighted (IDW) interpolation method (Mueller et al., 2004) to build the map.

\section{Results}

At the end of the two trapping phases, only the CTs of 77 locations worked normally. The other ten locations of CTs did not operate normally during the first phase and were not installed for the second phase. These 77 locations have accumulated 7583 camera trap days. Of the CTs which worked, 23 ones caught at least one $L$. cyclotis individual. Thus, the naïve occupancy of L. cyclotis in the TNP is $29.87 \%$. 
Table 1. Variance Inflation Factor of the explanatory variables

\begin{tabular}{|c|c|c|c|c|c|}
\hline Variables & Altitude & $\begin{array}{c}\text { Distance to the nearest research } \\
\text { or ecotourism area }\end{array}$ & $\begin{array}{c}\text { Distance to } \\
\text { periphery }\end{array}$ & $\begin{array}{c}\text { Distance to the } \\
\text { nearest water body }\end{array}$ & $\begin{array}{c}\text { Rate of } \\
\text { poaching index }\end{array}$ \\
\hline Variance Inflation Factor & 1.28 & 1.47 & 1.72 & 1.55 & 1.47 \\
\hline
\end{tabular}

Influence of explanatory variables on Loxodonta cyclotis distribution at the Taï National Park

The VIF of each of the different explanatory variables was less than 2.5 , i.e. the threshold value (Table 1). Thus, the five candidate variables were all retained for modelling.

Table 2 presents the models that we generated in order to verify the hypotheses according to which the L. cyclotis distribution in the TNP is positively influenced by the presence of researchers and ecotourists and negatively influenced by the pressure of poaching, the periphery of the Protected Area and the altitude. The first three models involving the variables «distance to the nearest research or ecotourism areas», «distance to the periphery» and «rate of poaching index» have Delta AIC $<2.0$. So, these models were the ones that best explained the L. cyclotis distribution in the TNP. Thus, the variables «distance to the nearest research or ecotourism areas», «distance to the periphery» and "rate of poaching index» were the best predictors of the L. cyclotis distribution in the TNP. Analysis of the results of models 1, 2 and 3 shows that the distance to the nearest research or ecotourism areas variable maintains a negative beta coefficient $(-0.093,-0.111$ and -0.096 , respectively). Thus, the occupancy probability of L. cyclotis increases with decreasing distance from the nearest research or ecotourism areas in the TNP. Also, the rate of poaching index variable has a negative beta coefficient $(-0.290$ for model 3), which suggests that any increase in poaching pressures is accompanied by a decrease in L. cyclotis probability of presence. However, the variable distance to the periphery has positive beta coefficients $(0.110$ and 0.091 for the models 1 and 3, respectively). This implies that any increase of distance to the periphery must be accompanied by an increase in the occupancy probability of L. cyclotis in the TNP.

\section{Predictive distribution of Loxodonta cyclo-} tis in the Taï National Park according to environmental characteristics

Using the results from the three best models, we have developed a predictive L. cyclotis distribution map for the TNP. This map shows two main L. cyclotis distribution areas. The first is in the northwestern part of the TNP, which covers the ecological research area. The second area was in the southwestern part of the Protected Area. It covers the Guiroutou ecotourism area. There is contact between the two L. cyclotis distribution areas in the axial part of the TNP, although the occupancy probability was relatively low compared to the two areas identified above. The eastern part of the TNP is the area with low probability of the L. cyclotis presence. In general, this distribution is more likely to be towards the western edge of the TNP than the east (Fig. 2).

Table 2. Comparison of models involving different variables

\begin{tabular}{|c|c|c|c|c|c|}
\hline Models & Co-variables & AIC & Delta AIC & AIC wgt & $\begin{array}{c}\text { Model } \\
\text { likehood }\end{array}$ \\
\hline Model 1 & Distance to nearest research or ecotourism areas and distance to periphery & 257.50 & 0.00 & 0.3714 & 1.00 \\
\hline Model 2 & Distance to nearest research or ecotourism areas & 258.19 & 0.69 & 0.2630 & 0.7082 \\
\hline Model 3 & $\begin{array}{l}\text { Distance to nearest research or ecotourism areas, distance to periphery and rate } \\
\text { of poaching index }\end{array}$ & 259.34 & 1.84 & 0.1480 & 0.3985 \\
\hline Model 4 & $\begin{array}{l}\text { Distance to nearest research or ecotourism areas, distance to periphery, rate of } \\
\text { poaching index and altitude }\end{array}$ & 260.47 & 2.97 & 0.0841 & 0.2265 \\
\hline Model 5 & Distance to periphery & 261.25 & 3.75 & 0.0569 & 0.1534 \\
\hline Model 6 & $\begin{array}{l}\text { Distance to nearest research or ecotourism areas, distance to periphery, distance } \\
\text { to nearest water body, rate of poaching index and altitude }\end{array}$ & 262.43 & 4.93 & 0.0316 & 0.0850 \\
\hline Model 7 & Rate of poaching index & 263.30 & 5.80 & 0.0204 & 0.0550 \\
\hline Model 8 & No variables & 264.15 & 6.65 & 0.0134 & 0.0360 \\
\hline Model 9 & Altitude & 265.70 & 8.20 & 0.0062 & 0.0166 \\
\hline Model 10 & Distance to nearest water body & 266.09 & 8.59 & 0.0051 & 0.0136 \\
\hline
\end{tabular}

Note: AIC: Akaike Information Criterion; Delta AIC: The difference in AIC between the best model and the model being compared; AIC wgt: Akaike weight, which is the proportion of the total amount of predictive power provided by the full set of models contained in the model being assessed. 


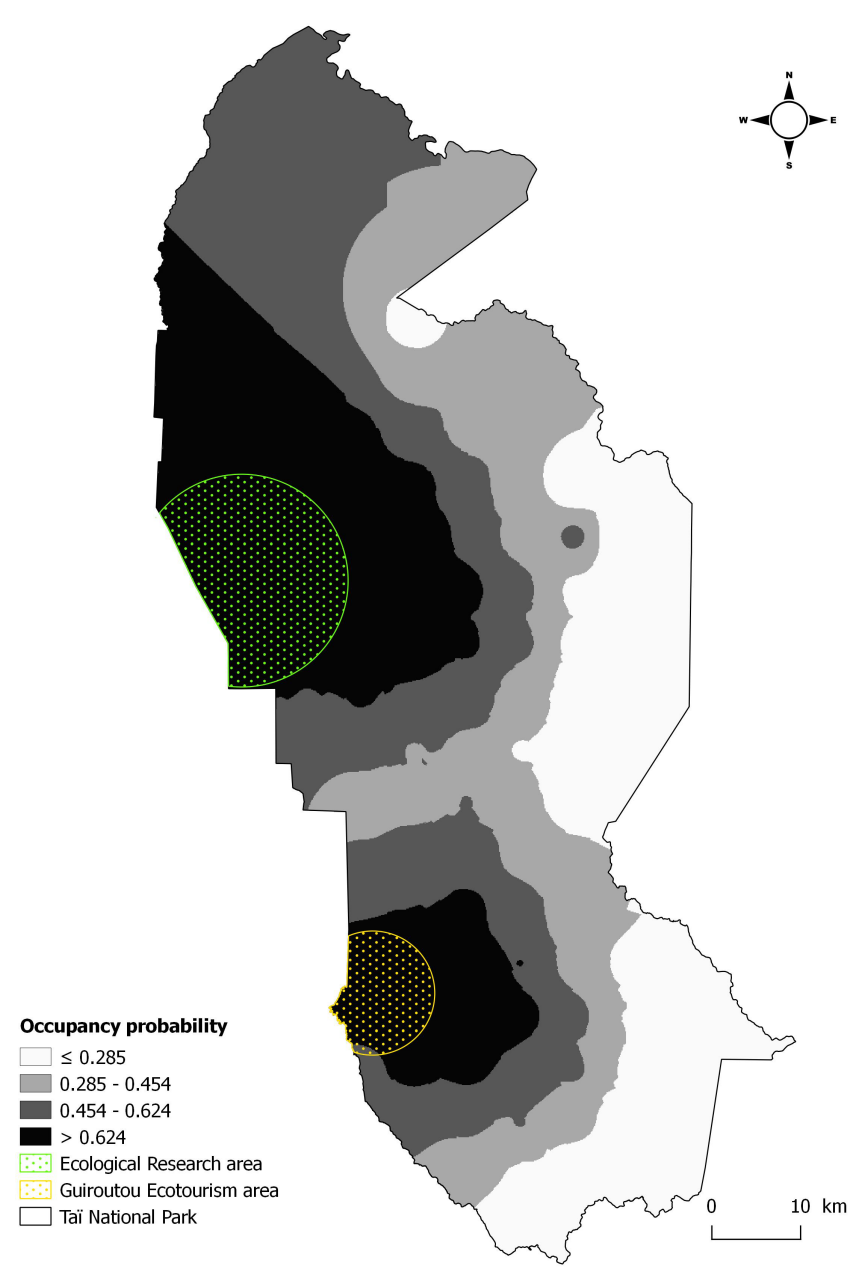

Fig. 2. Predictive distribution map of Loxodonta cyclotis in the Taï National Park.

\section{Discussion}

Our analysis of the factors influencing Loxodonta cyclotis distribution in the Taï National Park indicated that three variables are the best predictors of the species' distribution. These are «the rate of poaching index», "the distance to the nearest research or ecotourism areas» and «the distance to the periphery».

In the TNP, L. cyclotis occupancy probability showed a negative relationship with rate of poaching index, which reveals that the probability of L. cyclotis presence decreases with increasing rate of poaching index. A negative association between elephant distribution and poaching rates has also been demonstrated in the TNP by Boafo \& Nandjui (2011) and in the Bia-Goaso forest block in western Ghana (Danquah, 2016). Indeed, elephants are very sensitive to poaching pressure (Danquah, 2016; Ihwagi et al., 2018).

The variable «distance to the nearest research or ecotourism areas» has a negative relationship with the probability of the L. cyclotis presence in the Taï National Park, which reveals that the proximity to research or ecotourism areas is ac- companied by an increase in the probability of the L. cyclotis presence in the TNP. So, the poaching pressure and the research or ecotourism areas have opposite influences on the probability of $L$. cyclotis presence. This indicates a contribution of research and ecotourism areas (Ecological research area and Guiroutou ecotourism area) to the reduction on the poaching pressure on L. cyclotis in the TNP. This finding corroborates that of Campbell et al. (2011) who found that the proximity of research areas had a significant positive influence on the presence of duikers and primates in the TNP. Indeed, several studies have shown that research and ecotourism areas contribute to anti-poaching in the TNP. The almost permanent presence of researchers, ecotourists and eco-guides in these areas was a deterrent to poachers and other illegal operators in the Protected Area (Köndgen et al., 2008; Boafo \& Nandjui, 2011; Campbell et al., 2011; HoppeDominik et al., 2011; N'Goran et al., 2012). Such a contribution from the presence of researchers has been observed in Western Tanzania on the nine most common mammal species (Piel et al., 2015) and in the Dja Conservation Complex in Southeast Cameroon on great apes (Tagg et al., 2015). Also, Snyder et al. (2019) demonstrated that the risk of occurrence of illegal activities increases with increasing distance from scout camps in the western corridor of the Serengeti National Park in North Tanzania.

In the TNP, we found a positive relationship between the probability of L. cyclotis presence and distance to the Protected Area's periphery. Thus, there is a higher chance to observe $L$. cyclotis in the central part of the TNP than in the peripheral zone. Closer proximity to the periphery would negatively affect the $L$. cyclotis presence in the TNP. This observation can be explained by the fact that the periphery represents a combination of the impact of anthropogenic activities including poaching, agricultural activities, resource extraction (e.g. gold panning, non-wood forest products) and vehicle traffic (Bogui et al., 2016; Danquah, 2016; Diarrassouba et al., 2019). For example, Diarrassouba et al. (2019) found that areas with a high concentration of evidence of illegal human activity were located at the edge of the TNP, i.e. less than $10 \mathrm{~km}$ from the periphery. Indeed, poachers came to hunt on the outskirts at night and return before daybreak. To venture into more remote areas would imply a longer stay in the forest. This would require much more effort, 
not to mention the risk of being apprehended by surveillance officers. Distance to the periphery was also found to be a major predictor of the distribution of Choeropsis liberiensis (Bogui et al., 2016) and duiker species (Diarrassouba et al., 2019 ) in the TNP, by also showing a positive relationship. In Bia-Goasso Forest Block (Western Ghana), Danquah (2016) observed that elephants tended to avoid human settlements. On the contrary, Gaynor et al. (2018) found a high rate of daily elephant activity along the boundaries of Gorongosa National Park in Mozambique. They argued that the elephant presence in the peripheral area was justified by the availability of food resources, including crops. However, this presence in the peripheral zone was higher at night than during the daylight hours.

Analysis of the predictive L. cyclotis distribution map in the TNP shows two large areas with a high $L$. cyclotis occupancy probability. These are the northwestern part of the TNP and the southwestern part. These two preferred L. cyclotis distribution areas are located around the Ecological research area and Guiroutou ecotourism area. This confirms the positive impact of research and ecotourism areas on the L. cyclotis presence as mentioned above. However, this observation could be a result of the fact that the research and ecotourism areas were preferentially set up in areas of the TNP where the wildlife concentration was higher (Campbell et al., 2011). Certainly, the research and ecotourism areas were located in sites where viable Pan troglodytes (Blumenbach, 1799) populations existed. However, the choice of these areas was mainly for logistical reasons, namely the accessibility and availability of infrastructure (Campbell et al., 2011). Thus, according to Hoppe-Dominik et al. (2011) at the time of the creation of the research and ecotourism areas, the animal abundance was considerable in various parts of the TNP. But according to the present study, only two areas had maintained their animal population density after a decline in animal populations between 1977 and 2004, in the studied area of the Ecological research area and the Guiroutou ecotourism area. These results corroborate those of Boafo \& Nandjui (2011) and Tiedoué et al. (2018). However, the spatial gap between the two large areas inhabited by $L$. cyclotis, as reported by Boafo \& Nandjui (2011), is no longer a reality. Indeed, according to the $L$. cyclotis predictive distribution map and field observations, L. cyclotis distribution remains con- tinuous in the axial part of the TNP (Tiedoué et al., 2018), but the contact surface is limited and the occupancy probability is relatively low. This contact surface is likely to be a transition corridor between the two large areas with a high $L$. cyclotis concentration. In addition, this study shows that the L. cyclotis distribution in the TNP follows an east-west gradient, with a high occupancy probability in the west. Such a gradient has been shown for other species in the TNP, including Choeropsis liberiensis (Bogui et al., 2016) and all tail monkeys (N'Goran et al., 2012). In addition, Hoppe-Dominik et al. (2011) showed that the density of large mammal droppings in general followed strongly an east-west gradient. According to Hoppe-Dominik et al. (2011), these findings are due to the large number of infrastructures, the high density of the human population and the existence of large cities in the east of the TNP, unlike in the west. Thus, the eastern and the western areas of the TNP, are subject to considerably different hunting pressures and species habitat preferences (Hoppe-Dominik et al., 2011).

Our study suffers from some limitations. Indeed, our sampling locations did not cover the entire surface of the TNP, and we did not sample during all months or seasons of the year. Those limitations make it difficult to provide a precise predictive model. However, our study remains valid for a tropical rain forest where many locations can be inaccessible during the wet season. Furthermore, the relatively high humidity in such a tropical habitat compromised the functioning of ten of the total number of installed remote camera traps (Ancrenaz et al., 2012).

\section{Conclusions}

At the end of this study, it appears that the proximity to research or ecotourism areas has a positive impact on the L. cyclotis presence in the Taï National Park. At the same time, the proximity to the peripheral edges of the Protected Area and increasing poaching pressures are associated with a reduction in occupancy probability of $L$. cyclotis. The predictive distribution map of $L$. cyclotis in the TNP revealed two preferred areas of high elephant probability of presence. These are the research and ecotourism areas and their surroundings in the western part of TNP. Consequently, the eastern part of the Protected Area is associated with a low probability of L. cyclotis occupancy. These results confirm the positive effect of research and ecotourism activities favour 
L. cyclotis (and thus total wildlife) conservation. So, we recommend managers to be more collaborative with research and tourism professionals and to favour the establishment of more research sites and tourism camps, particularly on the eastern side of the TNP, currently most frequented by poachers. In addition, we invite the managers to strengthen the surveillance of the Protected Area.

\section{Acknowledgments}

We specially thank the Volkswagen Foundation for the financial support. We are very grateful to the Ivorian authorities, particularly, the Ministère de l'Environnement et du Développement Durable, and the Ivoirian Office of Parks and Reserves (Côte d'Ivoire), for their permission to conduct this research. We highly acknowledge the Swiss Centre for Scientific Research in Côte d'Ivoire (Côte d'Ivoire), the Jean Lorougnon Guédé University (Côte d'Ivoire) and the Max Planck Institute for Evolutionary Anthropology in Leipzig (Germany) for their various supports during this study. We gratitude to Elizabeth Kay (United Kingdom) and Bob Newman (United Kingdom) for taking their time to improve the English of this manuscript.

\section{References}

Allison P.D. 1999. Multiple regression: A primer. London: Sage. 220 p.

Ancrenaz M., Andrew J.H., Ross J., Sollmann R., Wilting A. 2012. Handbook for wildlife monitoring using cameratraps. Sabah: BBEC Publication. 57 p.

Ashiagbor G., Danquah E. 2017. Seasonal habitat use by Elephants (Loxodonta africana) in the Mole National Park of Ghana. Ecology and Evolution 7(11): 3784-3795. DOI: $10.1002 /$ ece 3.2962

Barima Y.S.S., Kouakou A.T.M., Bamba I., Sangne Y.C., Godron M., Andrieu J., Bogaert J. 2016. Cocoa crops are destroying the forest reserves of the classified forest of Haut-Sassandra (Ivory Coast). Global Ecology and Conservation 8: 85-98. DOI: 10.1016/j.gecco.2016.08.009

Boafo Y., Nandjui A. 2011. Report on the survey of elephants in the Taï National Park in southwestern Côte d'Ivoire. MIKE. Technical report. 35 p.

Bogui E.B., Koffi A.D., Koné I., Ouattara K., Kouakou Y.C., Gnangbo A. 2016. Distribution of Pygmy hippopotamus (Choeropsis liberiensis) in Taï National Park, Ivory Coast: Influences of natural and anthropogenic factors. International Journal of Research in Biosciences 5(4): 27-35.

Bouché P., Douglas-Hamilton I., Wittemyer G., Nianogo A.J., Doucet J.L., Lejeune P., Vermeulen C. 2011. Will Elephants Soon Disappear from West African Savannahs? PLoS ONE 6(6): e20619. DOI: 10.1371/journal. pone.0020619

Burton A.C., Neilson E., Moreira D., Ladle A., Steenweg R., Fisher J.T., Bayne E., Boutin S. 2015. Wildlife camera trapping: a review and recommendations for linking surveys to ecological processes. Journal of Applied Ecol- ogy 52(3): 675-685. DOI: 10.1111/1365-2664.12432

Campbell G., Kuehl H., Diarrassouba A., N'Goran P.K., Boesch C. 2011. Long-term research sites as refugia for threatened and over-harvested species. Biology Letters 7(5): 723-726. DOI: 10.1098/rsbl.2011.0155

Caspary H.U., Koné I., Prouot C., De Pauw M. 2001. La chasse et la filière viande de brousse dans l'espace Taï, Côte d'Ivoire. Tropenbos-Côte d'Ivoire. série 2. 98 p.

Chase M.J., Schlossberg S., Griffin C.R., Bouché P.J., Djene S.W., Elkan P.W., Ferreira, S., Grossmann F., Kohi E.M., Landen K., Omondi P., Peltier A., Selier S.A.J., Sutcliffe R. 2016. Continent-wide survey reveals massive decline in African savannah elephants. PeerJ 4: e2354. DOI: $10.7717 /$ peerj.2354

Chatelain C., Kadjo B., Koné I., Refisch J. 2001. Relations Faune-Flore dans le Parc National de Taï: une étude bibliographique. Tropenbos-Côte d'Ivoire. $166 \mathrm{p}$.

Craigie I.D., Baillie J.E., Balmford A., Carbone C., Collen B., Green R.E., Hutton J.M. 2010. Large mammal population declines in Africa's protected areas. Biological Conservation 143(9): 2221-2228. DOI: 10.1016/j.biocon.2010.06.007

Danquah E. 2016. Spatial Distribution of Elephants versus Human and Ecological Variables in Western Ghana. Advances in Ecology 2016: 8038524. DOI: $10.1155 / 2016 / 8038524$

Diarrassouba A., Gnagbo A., Kouakou Y.C., Campbell G., Tiedoué M.R., Tondossama A., Kühl H.S., Koné I. 2019. Differential response of seven duiker species to human activities in Taï National Park, Côte d'Ivoire. African Journal of Ecology 58(1): 58-68. DOI: 10.1111/aje. 12680

Douglas-Hamilton I. 1987. African elephants: population trends and their causes. Oryx 21(1): 11-24. DOI: 10.1017/S0030605300020433

Gaynor K.M., Branco P.S., Long R.A., Gonçalves D.D., Granli P.K., Poole J.H. 2018. Effects of human settlement and roads on diel activity patterns of elephants (Loxodonta africana). African Journal of Ecology 56(4): 872-881. DOI: 10.1111/aje.12552

Hetem R.S., Fuller A., Maloney S.K., Mitchell D. 2014. Responses of large mammals to climate change. Temperature 1(2): 115-127. DOI: 10.4161/temp.29651

Hines J.E. 2006. PRESENCE software to estimates patch occupancy rates and related parameters. Laurel, Maryland: Patuxent Wildlife Research Center. Available from www.mbr-pwrc.usgs.gov/software/presence.html

Hoppe-Dominik B., Kühl H.S., Radl G., Fischer F. 2011. Long-term monitoring of large rainforest mammals in the Biosphere Reserve of Taï National Park, Côte d'Ivoire. African Journal of Ecology 49(4): 450-458. DOI: $10.1111 / \mathrm{j} .1365-2028.2011 .01277 . \mathrm{x}$

Ihwagi F.W., Thouless C., Wanga T., Skidmorea A.K., Omondi P., Douglas-Hamilton I. 2018. Night-day speed ratio of elephants as indicator of poaching levels. Ecological Indicators 84: 38-44. DOI: 10.1016/j. ecolind.2017.08.039

Kely M.R., Kouakou C.Y., Béné J.C.K., Koffi A.D., N'Guessan K.A., Tiedoué M.R. 2019. Spatial distribu- 
tion and period of activity of the forest elephant (Loxodonta africana cyclotis) at Taï National Park, south western Côte d'Ivoire. Journal of Applied Biosciences 133(1): 13542-13551. DOI: 10.4314/jab.v133i1.6

Kolongo D.T.S., Decocq G., Yao C.Y.A., Blom E.C., Van Rompaey R.S.A.R. 2006. Plant species diversity in the southern part of the Taï National Park (Côte d'Ivoire). Biodiversity and Conservation 15(7): 2123-2142. DOI: 10.1007/s10531-004-6686-1

Komena K.B. 2014. Recompositions de l'espace Taï et gouvernance du parc national dans un contexte de crise (Sud-Ouest de la Côte d'Ivoire). Ethics and Economics 11(1): 126-144.

Konaté S., Kampmann D. (Eds.). 2010. Biodiversity Atlas of West Africa. Vol. 3: Côte d'Ivoire. Abidjan \& Frankfurt/ Main. 526 p.

Köndgen S., Kühl H., N'Goran P.K., Walsh P.D., Schenk S., Ernst N., Biek R., Formenty P., Mätz-Rensing K., Schweiger B., Junglen S., Ellerbrok H., Nitsche A., Briese T., Lipkin W.I., Pauli G., Boesch C., Leendertz F.H. 2008. Pandemic human viruses cause decline of endangered great apes. Current Biology 18(4): 260 264. DOI: 10.1016/j.cub.2008.01.012

Kouakou J.L., Gonedelé Bi S., Bitty E.A., Kouakou C., Yao A.K., Kassé K.B., Ouattara S. 2020. Ivory Coast without ivory: Massive extinction of African forest elephants in Côte d'Ivoire. PLoS ONE 15(10): e0232993. DOI: 10.1371/journal.pone.0232993

MacKenzie D.I., Nichols J.D., Lachman G.B., Droege S., Royle A.J., Langtimm C.A. 2002. Estimating site occupancy rates when detection probabilities are less than one. Ecology 83(8): 2248-2255. DOI: 10.1890/0012-9658(2002)083[2248:ESORWD]2.0.CO;2

MacKenzie D.I., Nichols J.D., Royle J.A., Pollock K.H., Bailey L.L., Hines J.E. 2006. Occupancy estimation and modeling: inferring patterns and dynamics of species occurrence. Burlington: Elsevier. 324 p.

Maisels F., Strindberg S., Blake S., Wittemyer G., Hart J., Williamson E.A., Aba'a R., Abitsi G., Ambahe R.D., Amsini F., Bakabana P.C., Hicks T.C., Bayogo R.E., Bechem M., Beyers R.L., Bezangoye A.N., Boundja P., Bout N., Akou M.E., Bene L.B., Fosso B., Greengrass E., Grossmann F., Ikamba-Nkulu C., Ilambu O., Inogwabini B.I., Iyenguet F., Kiminou F., Kokangoye M., Kujirakwinja D. et al. 2013. Devastating decline of forest elephants in Central Africa. PloS ONE 8(3): e59469. DOI: 10.1371/journal.pone.0059469

Mueller T.G., Pusuluri N.B., Mathias K.K., Cornelius P.L., Barnhisel R.I., Shearer S.A. 2004. Map quality for ordinary kriging and inverse distance weighted interpolation. Soil Science Society of America Journal 68(6): 2042-2047. DOI: 10.2136/sssaj2004.2042

N'Goran K.P., Boesch C., Mundry R., N'Goran E.K., Herbinger I., Yapi F.A., Kühl H.S. 2012. Hunting, law enforcement, and African primate conservation. Conservation Biology 26(3): 565-571. DOI: 10.1111/j.15231739.2012.01821.x

Ngama S., Korte L., Johnson M., Vermeulen C., Bindelle J. 2018. Camera traps to study the forest elephant's (Loxo- donta cyclotis) response to chilli pepper repellent devices in Gamba, Gabon. Nature Conservation Research 3(2): 26-35. DOI: 10.24189/ncr.2018.027

O’Connell A.F., Nichols J.D., Karanth K.U. 2011. Camera Traps in Animal Ecology. Tokyo: Springer Japan. 271 p.

OIPR. 2014. Plan d'aménagement et de gestion du parc national de Taï 2014-2018. Abidjan, Côte d'Ivoire. 131 p.

Ousmane S., N'da Dibi H., Kouassi K.H., Kouassi K.E., Ouattara K. 2020. Crises politico-militaires et dynamique de la végétation du Parc national du Mont Péko en Côte d'Ivoire. Bois \& Forêts des Tropiques 343: 27-37.

Piel A.K., Lenoel A., Johnson C., Stewart F.A. 2015. Deterring poaching in western Tanzania: The presence of wildlife researchers. Global Ecology and Conservation 3: 188-199. DOI: 10.1016/j.gecco.2014.11.014

Ripple W.J., Estes J.A., Beschta R.L., Wilmers C.C., Ritchie E.G., Hebblewhite M., Berger J., Elmhagen B., Letnic M., Nelson M.P., Schmitz O.J, Smith D.W., Wallach A.D., Wirsing A.J. 2014. Status and ecological effects of the world's largest carnivores. Science 343(6167): 1241484. DOI: $10.1126 /$ science. 1241484

Rovero F., Martin E., Rosa M., Ahumada J.A., Spitale D. 2014. Estimating species richness and modelling habitat preferences of tropical forest mammals from camera trap data. PLoS ONE 9(7): e103300. DOI: 10.1371/ journal.pone. 0103300

Scouppe M. 2011. Composition floristique et diversité de la végétation de la zone Est du Parc National de Taï (Côte d'Ivoire). Master Université de Genève. 194 p.

Snyder D.K., Mneney P.B., Wittemyer G. 2019. Predicting the risk of illegal activity and evaluating law enforcement interventions in the western Serengeti. Conservation Science and Practice 1(9): e81. DOI: 10.1111/csp2.81

Tagg N., Willie J., Duarte J., Petre C.A., Fa J.E. 2015. Conservation research presence protects: a case study of great ape abundance in the Dja region, Cameroon. Animal Conservation 18(6): 489-498. DOI: 10.1111/acv.12212

Thouless C.R., Dublin H.T., Blanc J.J., Skinner D.P., Daniel T.E., Taylor R.D., Maisels F., Frederick H.L., Bouché P.P. 2016. African Elephant Status Report 2016: an update from the African Elephant Database. Occasional Paper Series of the IUCN Species Survival Commission, №60 IUCN / SSC Africa Elephant Specialist Group. Gland, Switzerland: IUCN. 309 p.

Tiedoué M.R., Koné S.S., Diarrassouba A., Tondossama A. 2018. Etat de conservation du Parc national de Taï: Résultats du suivi écologique, Phase 12. Soubré, Côte d'Ivoire: Office Ivoirien des Parcs et Réserves \& Direction de Zone Sud-ouest. 37 p.

Wittemyer G., Northrup J.M., Blanc J., Douglas-Hamilton I., Omondi P., Burnham K.P. 2014. Illegal killing for ivory drives global decline in African elephants. Proceedings of the National Academy of Sciences of the United States of America 111(36): 13117-13121. DOI: 10.1073/pnas. 1403984111

Yao C.A., N'Guessan E.K. 2005. Botanical diversity of the South of Taï National Park, Côte d'Ivoire. Afrique Science 1(2): 295-313. 


\title{
ИССЛЕДОВАНИЯ И ТУРИЗМ ПОЛОЖИТЕЛЬНО ВЛИЯЮТ НА РАЗМЕЩЕНИЕ LOXODONTA CYCLOTIS (ELEPHANTIDAE) В НАЦИОНАЛЬНОМ ПАРКЕ ТАЙ (КОТ-Д'ИВУАР)
}

\author{
М. Р. Кели ${ }^{1,2} \mathbb{D}$, С. Й. Коуакоу ${ }^{1,2} \mathbb{D}$, Ж.-К. К. Бене ${ }^{1 \mathbb{D}}$, М. Р. Тьедуэ ${ }^{3}$, \\ А. Диаррасуба ${ }^{3}$, А. Тондоссама ${ }^{3}$, Я. С. Кюль ${ }^{4} \mathbb{D}$, М. Уолтерт $^{5} \mathbb{D}$ \\ ${ }^{1}$ Университет Жана Лоруньона Геде, Кот-д’Ивуар \\ e-mail:malekely@gmail.com,celestykoua18@gmail.com,benejc@gmail.com \\ ${ }^{2}$ Швейцарский центр научных исследований в Кот-д'Ивуар, Кот-д 'Ивуар \\ ${ }^{3}$ Управление парков и заповедников Кот-д 'Ивуар, Кот-д’'Ивуар \\ e-mail: tiedouer@gmail.com,abdoulaye.diarrassouba@oipr.ci,adama.tondossama@oipr.ci \\ ${ }^{4}$ Институт эволюиионной антропологии общества Макса Планка, Германия \\ e-mail:kuehl@eva.mpg.de \\ ${ }^{5}$ Геттингенский университет имени Георга-Августа, Германия \\ e-mail:mwalter@uni-goettingen.de
}

В Африке все шире признается сокращение и изоляция популяций дикой мегафауны. В Кот-д’Ивуар, где слоны являются национальным символом, Национальный парк Тай (ТНП) является ключевым сохранившимся местом обитания Loxodonta cyclotis. Однако взаимоотношения между L. cyclotis и coвременными условиями окружающей среды менее изучены. Настоящее исследование направлено на определение факторов, влияющих на особенности занятости местообитаний этого вида в ТНП с целью принятия решений по сохранению популяции. Мы оценили вероятность занятости местообитаний особями Loxodonta cyclotis и факторы, влияющие на распространение вида, на основе переменных среды обитания и наблюдений, полученных с помощью 87 фотоловушек, установленных в течение 120 дней на территории ТНП. Мы использовали модель занятости для определения переменных, которые оказывают статистически значимое влияние на распространение L. cyclotis, и для оценки вероятности занятости местообитаний в зависимости от места установки фотоловушек. Мы также составили прогнозную карту распространения вида путем интерполяции значений вероятности занятости участков в местах установки фотоловушек. Ключевыми факторами, определяющими распространение L. cyclotis в ТНП, были расстояние до ближайших участков исследования или участков, используемых для целей экотуризма, расстояние до периферии ТНП и уровень браконьерства на месте установки фотоловушки. Таким образом, вероятность занятости местообитаний уменьшалась по мере приближения к периферии ТНП и усиления фактора браконьерства, в то время как наблюдалось увеличение вероятности по мере приближения к участкам исследования или районам, используемым для экотуризма. Прогнозная карта распространения вида показала, что северо-западные и юго-западные районы ТНП имеют более высокую вероятность ( $>$ 0.6) появления L. cyclotis по сравнению с другими участками особо охраняемой природной территории. Полученные результаты подтверждают положительный эффект научных исследований и экотуризма, способствующих сохранению L. cyclotis и, следовательно, других объектов дикой природы. Поэтому эти виды деятельности рекомендуется продвигать вместе со стратегиями борьбы с браконьерством.

Ключевые слова: модель занятости местообитаний, особо охраняемая природная территория, сохранение слонов, фактор распространения, фотоловушка 